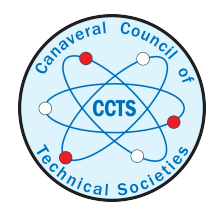

The Space Congress ${ }^{\circledR}$ Proceedings

1971 (8th) Vol. 1 Technology Today And

Tomorrow

Apr 1st, 8:00 AM

\title{
Facilities Planning Approach for the Space Shuttle
}

\author{
J. T. Rose
}

Manager, Operations and Implementation, Space Shuttle Program, McDonnell Douglas Astronautics

Company -Eastern Division

Follow this and additional works at: https://commons.erau.edu/space-congress-proceedings

\section{Scholarly Commons Citation}

Rose, J. T., "Facilities Planning Approach for the Space Shuttle" (1971). The Space Congress ${ }^{\circledR}$

Proceedings. 4.

https://commons.erau.edu/space-congress-proceedings/proceedings-1971-8th/session-11/4

This Event is brought to you for free and open access by the Conferences at Scholarly Commons. It has been accepted for inclusion in The Space Congress ${ }^{\circledR}$

Proceedings by an authorized administrator of Scholarly Commons. For more information, please contact commons@erau.edu.

EMBRYARDDLE Aeronautical University SCHOLARLY COMMONS 


\title{
FACILITIES PLANNING APPROACH
}

FOR THE SPACE SHUTTLE

\author{
J. T. Rose \\ Manager, Operations and Implementation \\ Space Shuttle Program \\ McDonnel1 Douglas Astronautics Company - Eastern Division \\ St. Louis, Missouri
}

\section{ABSTRACT}

In developing an overall facilities plan for the Space Shuttle program, it is important to recognize that manufacturing, development, and operations requirements cannot be independently developed. While it is true that specific requirements for each element can be developed independently, applying these requirements to candidate locations can only result in an optimized facilities plan when the appropriate interrelationships of all program elements are properly assessed. Starting with an understanding both of the Shuttle vehicles and of the overall assembly flow, this paper discusses the MDC study of the overall manufacturing, test, and operations requirements for facilities. It also demonstrates the various interrelationships that must be recognized and studied before a recommended facilities plan can be effectively developed.

\section{INTRODUCTION}

The Space Shuttle will require the use of numerous existing government and industrial facilities. In order to establish the optimal utilization concept, it is necessary to identify and study booster and orbiter requirements from the initial manufacturing process, through testing, to operations. of particular importance is the definition of those commonalities which will result in total program costs reductions. For each vehicle, consideration must be given to many program requirements affecting the total facility planning concept.

One major requirement involves the implementation schedule, which must be compatible with the program milestones and, at the same time, must be realistically cognizant of the time necessary to design, construct, and activate the Shuttle facilities. Additionally, continuous analysis must compare a variety of techniques for vehicle handling, assem- bly, checkout, servicing, etc. to determine the most effective methods for the complete Shuttle system. One initial activity involves the definition of key facilities and corresponding interrelationships. Such definttion provides traceability for a specific requirement, as well as indicating $i$ ts impact on other considerations. For each major manufacturing, development, and operation activity, a progressively detailed evaluation of existing facilities is required in order to determine site facility capabilities (size, location, constraints, etc.). Additionally, transportation systems (air, rail, road, water) are vitally important for the shipment of materials and assemblies to and from candidate locations. The avallability or limitations of transportation systems will directly effect the amount of work accomplished at a particular site. Results of this evaluation thoroughly describe the capability of potential sites to support the Shuttle program.

\section{SHUTTLE GROUND RULES}

In developing the facility plan, a number of program and contractor ground rules have been established as depicted below which influence the primary objectives of this plan.

- Program master schedule milestones

- Reduce nonrecurring and recurring costs

- Final assembly location must have horizontal take off capability

- Maintenance, launch, landing and turnaround at same location

- Initial horizontal flights will be from final assembly site

o Site evaluation study shall consider new and existing sites

- Two week (or less) ground turnaround

- Launch rates 25 - 75 flights per year 
- Maximum use of existing facilities

- Minimum exposure to adverse envi romment

- Minimum assembly and checkout requirements at

the launch pad

The progran master schedule identifies a series of major inflestones which effect the factlity planning concept. In addition, major emphasis has been placed on mintmizing both nonrecurring and recurring cost, and on making maximum use of existing capabilities. From these, subordinant ground rules for each of the three najor phases have been established. For example, for the manufacturing phase, elimination of redundancy and transportability for development testing and operations is considered essential for successful implementation. In the devalepment phase, test commonality, use of aircraft test methods, and multi-use of major test articles are key ground rules. The major Operational phase rules are keyed to two weeks, or less, ground turnaround, and to centralized maintenance, launch, and landing operations.

\section{VEMICLE DESCRIPTIOM}

As shown in Figures 1 and 2, the Shuttle vehicles are generally simllar in size to present day "jumbo" afreraft. Consfdering the overall size of SIZE COMPARISON Shuttle Booster ys C-5A Galaxy

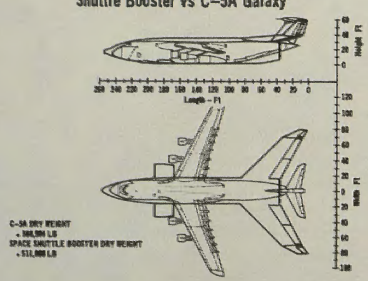

FIGURE ]

these vehicles, it is ebvious that handling and transportation must be a primary consideration in developing the facility plan. During the manufacturing phase, the vehicles nay be partially assembled prior to shiprent to a final assenbly site. The major assemblfes may be menufactured at different locations, or combinations of assembiles may be designated for manufacture at one location.

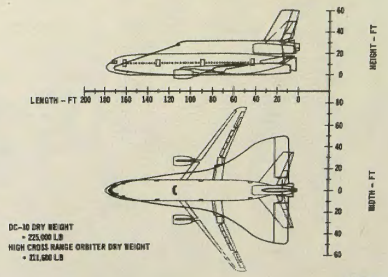

FIGURE 2

This can only be determined when manufacturing and test requirements are defined, and schedule considerations are thoroughly analyzed. Figure 3 shows the major booster assemblies. This vehicle's

FINAL ASSEMBLY

Wanufacturing Assembly Sequence - Booster

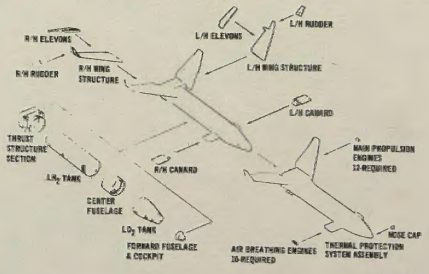

FIGURE 3

largest module is the nain 19quid hydrogen tank. Upon completion of manufacturing, the tank assently will be rotated to the horizontal position on a mobile transporter, and then is moved to the assembly area. The moblle transporters provide the capability of adjusting the tank assenbly position for mating of other modules. Prior to mating of the $\mathrm{LO}_{2}$ tank assembly, the transporter unit is removed, leaving the main assembly on its:landing gear. Subsequently, the $\mathrm{LO}_{2}$ tank and nose section modules are mated to the main assembly. Upon completion of this activity, a prime nover unt is positioned under the forward landing gear and the complete assexbly is prepared for shipment. Final assenbly operations will consist prixarlly of attachnent of wing and fin assemblies, canards, 
airbreathing engines, and main propulsion engines. Figure 4 shows the major high cross range orbiter subassemblies and assembly flow. The assembly concept will be similar to that previously described for the booster. Final assembly will involve installation of a greater quantity of modules, including wings, main landing gear, vertical stabilizers, elevons, body flap, ABES, and main engines.

Movement of major subassemblies will requitre the use of a variety of transportation techniques. A thorough evaluation of barge, air, rail, and road systems defines the candidate methods of moving the vehicle assemblies. Depending on the location of manufacturing and development activities, the most efficient method of shipment will be designated for combinations of primary subassemblies. As shown in Figure 5, the majority of assemblies are adaptable to a variety of transportation systems. The final system selected will depend on integrated study of the complete manufacturing, development, and operations requirements of all program elements.
SPACE SHUTTLE COMPONENT

TRANSPORTATION ANALYSIS

Transportation Capabilities

\begin{tabular}{|c|c|c|c|c|}
\hline STFUCTURE TRANSPORTATIOM MODE & BARGE & AIR & AMIL & คลAO \\
\hline 1. CAEN CONPARTVEKT IOREITERA & $\bullet$ & $\bullet$ & & \\
\hline 2. FORKAFO FUSELAOE, BODSTERI & 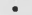 & $\bullet$ & & \\
\hline 1. NOSE SECTION IOREITERI & - & - & $\bullet$ & $\bullet$ \\
\hline 4. CAYARD IBCOSTER: & $\bullet$ & - & & \\
\hline 5. WING $B O O D T E R$ & $\bullet$ & & & \\
\hline 6. DELTA WING NOREITERT & $\bullet$ & & & \\
\hline 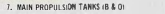 & $\bullet$ & & & \\
\hline 8. SE COMGSRY TAESS IB S O & - & $\bullet$ & • & $\bullet$ \\
\hline 9. MAIM FUEELAGE \& $\&$ Q DI & - & & & \\
\hline 10. EMCIAE POOS IDQBeTER DE LTA & - & $\bullet$ & - & \\
\hline II. CARGO DCORS IOREITERS DELTA & $\bullet$ & $\bullet$ & $\bullet$ & \\
\hline 12. AFT FUSELAGE IBOOSTERI & $\bullet$ & & & \\
\hline 13. VERIICAL FIN IBOOSTERI & $\bullet$ & & & \\
\hline 16. VERTICAL FAM IOREITERI & $\bullet$ & $\bullet$ & $\bullet$ & - \\
\hline 15. CONTROL SGERFACES & $\bullet$ & $\bullet$ & - & - \\
\hline 16. DE TAIL PARTS & $\bullet$ & - & $\bullet$ & 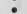 \\
\hline
\end{tabular}

FIGURE 5

\section{MANUFACTURING FACILITIES REQUIREMENTS}

In determining manufacturing facility requirements for the Space Shuttle program, the methodology depicted in Figure 6 has been utilized. It was first necessary to analyze the overall dimensions and configuration of both orbiter and booster. Once size and configuration was determined, a manufacturIng study utilizing design configuration analyses,

FINAL ASSEMBLY

Manufacturing Assembly Sequence - Delta Wing Orbiter
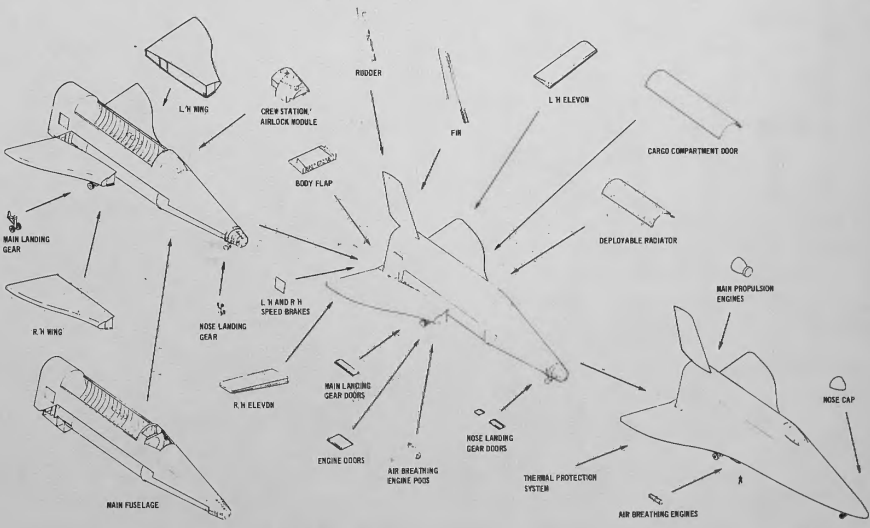

FIGURE 4 
METHODOLOGY FOR DETERMINING MANUFACTURING

FACILITIES REQUIREMENTS

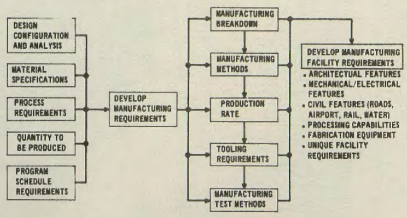

FIGURE 6

material specification, process requirements, quantity to be produced, and program schedules was conducted to determine how the structure should be broken down into manageable major subassemblies. Of necessity, ease of handling and fabrication were important considerations. At this point, the manufacturing requirements for each subassembly were developed. Detalled manufacturing breakdowns for each major subassembly were used to detemine methods, tooling, manufacturing testing, and production rates in accordance with the overall Master Schedule and Shuttle Major Milestones.

From an analysis of manufacturing requirements, detafled facility requirements are developed. Such parameters as architectural, mechanical, electrical, and civic features are defined. Processing capabilities, fabrication equipment, manpower, and skill availability are also necessary in establishing factility needs.

Due to the uniqueness and size of many of the Shuttle vehicle subassemblies, a parallel activity of analyzing existing government and contractor facilities has been underway since the beginning of the Phase B program. This has been, and will continue to be, an iterative process, because only when the detailed manufacturing requirements are defined to adequate depth can a complete faclifty definition be accomplished. However, such a parallel facility investigation is quite important for a general assessment of the capabilities and limitations of existing facilities and their geographical locations.

As an example of the process defined above, the manufacturing breakdown for the current booster vehicle configuration consists of the following subassemblies:

o main fuselage assembly

o forward fuselage/cockpit section

- LoX tank fuselage section

- center fuselage section

- $\mathrm{LH}_{2}$ tank fuselage section

o aft fuselage/thrust structure section

- $\mathrm{L} / \mathrm{H}$ and $\mathrm{R} / \mathrm{H}$ canard assemblles

$0 \mathrm{~L} / H$ and $R / H$ wing assemblies

$0 \mathrm{~L} / \mathrm{H}$ and $\mathrm{R} / \mathrm{H}$ vertical fins

- $L / H$ and $R / H$ elevons

$0 \mathrm{~L} / \mathrm{H}$ and $\mathrm{R} / \mathrm{H}$ rudders

o thermal protection system

Taking the main liquid hydrogen $\left(\mathrm{LH}_{2}\right)$ tank as an example, Figure 7 depicts how the major components are assembled. This tank, when completed, will be

\section{$\mathrm{LH}_{2}$ TANK}

Manufacturing Assembly Sequence - Booster

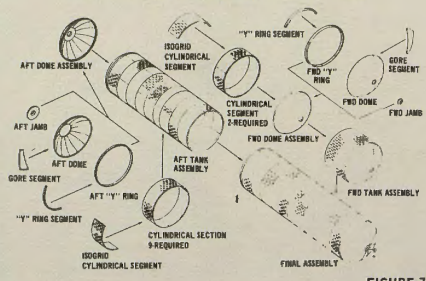

FIGURE 7

$134 \mathrm{ft}$ long by $34 \mathrm{ft}$ in diameter, and wi 11 weigh approximately $48,550 \mathrm{lb}$. It will be build principally of aluainum plate stock and forgings (consisting of cylindrical tank skins, rings, end domes, and access port jamb rings). Some of the manufacturing techniques required consist of:

a isogrid pocket machining

o stretch forming

- power brake and roll forming

- elevated temperature aging

0 chemical milling and processing

0 welding

- X-rajing

- pressure and leak testing

In general, the manufacturing sequence for this tank will consist of taking machined parts after forming, aging, processing, inspection, etc., and assembling them by welding to form tank rings, 
cylindrical skin, and end dome tank sections. These tank sections, in turn, will be joined and welded in a specific sequence using a vertical weld tower; they will then be progressively pressure and leak tested, using a modified pneumostatic test technique.

From these typical manufacturing requirements for the $\mathrm{LH}_{2}$ tanks, facillty requilements (shown in Figure 8 ) have been developed. In addition to

\section{MANUFACTURING AND TEST FACILITY REQUIREMENTS - BOOSTER LH 2 TANK}

\begin{tabular}{|c|c|}
\hline Discipuats. & RECSingetnTs \\
\hline $\begin{array}{l}\text { FHALL RSSEWELY AREA } \\
\text { OCLLAR HEIGHT } \\
\text { - CRAHE CAPACITY }\end{array}$ & 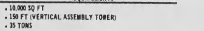 \\
\hline 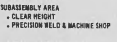 & 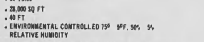 \\
\hline MARUFACTUGME EQUIPUEAT & 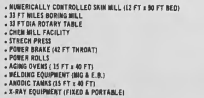 \\
\hline roounta & 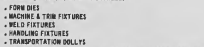 \\
\hline 1ร9тike & 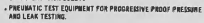 \\
\hline $\begin{array}{l}\text { OfFice } \\
\text { TRQuBPoRTATISE }\end{array}$ & $\begin{array}{l}\text { - } 12 \text { be मे FT } \\
\text { - Bunge }\end{array}$ \\
\hline STORACE & . NOEQUATE FOR MAR STOCK G QCTAL PARTS \\
\hline
\end{tabular}

FIGURE 8

square footage of floor space, clear height, and environmental needs for fabrication and assembly areas, specific manufacturing equipment is important in the facility analysis because of the size of the Shuttle vehicles and their components. As an example, the $33 \mathrm{ft}$ boring $\mathrm{mfll}$ and rotary table are significant items. In addition, machining, forming, processing, inspection, and test equipment must be capable of handling unusually large parts and assemblies. Also, as in all programs, tooling is extremely costly.

Taking individual manufacturing and facility requirements for each major subassembly, it is important to compare these with requirements for other major subassemblies, to determine similar or common requirements (for example, the similarity between the booster liquid hydrogen $\left[\mathrm{LH}_{2}\right]$ and liquid oxygen [LOX] tanks). In addition, similarities between booster and orbiter vehicles should be analyzed from a manufacturing and facilities requirement viewpoint to identify commonalities. From these comparisons and analyses, an optimal approach for manufacturing, facilities utilization, and logical manufacturing locations can be determined. However, unt1l the manufacturing and facilities approach is compared against the development testing and operations requirements, a total facilities location and utllization plan cannot be developed.

GROUND DEVELOPMENT AND VERIFICATION TEST FACILITIES REQUIREMENTS

Siting of ground tests must be considered within the total framework of planning efficient utilization of facilities for the Space Shuttle program. Initially, individual test facility requirements may be established independently of facilities planning for other program activities. Figure 9 shows the study methodology for establishing specifications for individual test facilities.

\section{METHODOLOGY FOR DETERMINING GROUND TEST FACILITIES REQUIREMENTS}

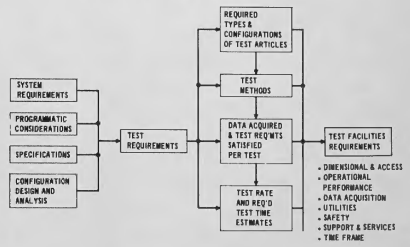

FIGURE 9

It should be noted that, prior to establishing test facility requirements, the actual test requirements for the Shuttle vehicles must be developed. Test requirements are established by a process of interrelating system requirements, programmatic considerations, pertinent specification, and information resulting from design and manufacturing engineering activities. These requirements will continue to change (or will become more definitive) as more is known about the configurations, but it is important to establish a reference baseline in order to continue planning toward establishing facility needs. When test requirements are analyzed to determine required test articles, test methods to be used, data requirements, and test rates and time estimates, test facility requirements can then be established. These requirements, in general, will specify dimenstions and access, performance, data acquisition, utilities, safety, support services, and scheduling criteria. 
Through prelfminary studies using the above processes, major testing activities for the Space Shuttle Phase $C$ and D program have been identified (as outlined in Figure 10). The testing activities,

\section{RELATIONSHIPS OF MAJOR GROUND TEST ACTIVITIES} TO OTHER PROGRAM ACTIVITIES

\begin{tabular}{|c|c|c|c|c|c|}
\hline \multirow[b]{2}{*}{ Woe TEmas AcTwm } & \multirow{2}{*}{$\begin{array}{l}\text { Easingraine } \\
\text { MUO DEsian }\end{array}$} & \multicolumn{2}{|c|}{ mamufactikus } & \multicolumn{2}{|c|}{$\begin{array}{l}\text { Fught } \\
\text { TET }\end{array}$} \\
\hline & & 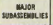 & $\begin{array}{c}\text { Fanc } \\
\text { atressir }\end{array}$ & nTo & vite \\
\hline 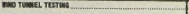 & $=x$ & & & & \\
\hline 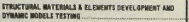 & 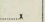 & & & & \\
\hline 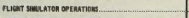 & $x$ & & & & \\
\hline 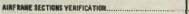 & 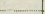 & $\ldots x$ & & & \\
\hline 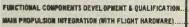 & $x$ & & & & $x$ \\
\hline 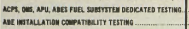 & $-\sin x$ & $x$ & & & \\
\hline 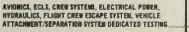 & $\ldots x$ & & & & \\
\hline 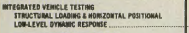 & & & $-x$ & & \\
\hline 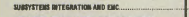 & & & $\ldots . . . x$ & $x$ & $x$ \\
\hline 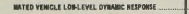 & & & & & $x$ \\
\hline 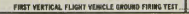 & & & & & $x$ \\
\hline
\end{tabular}

FIGURE 10

by their very nature, tend to be aligned with other program activities. As an example, verification tests of airframe sections interrelate with the manufacture of the major vehicle airframe subassemblies. Generally, testing activities become less independent and more interrelated with manufacturing/assembly and flight preparation as time progresses and program development matures.

For each of the major test requirements depicted in Figure 10, preliminary test facility requirements have been generated through the processes outlined in Figure 9. To 1llustrate one example of these test requirements, airframe sections verification test articles and test types are deplcted in F1gure 11. Major dedicated structural test articles for the booster are:

o rudder

- elevon

0 wing, and fin with aft thrust structure

o forward fuselage

- main $\mathrm{LH}_{2}$ tank

- Intertank section with canard

- $\mathrm{LO}_{2}$ tank section

- nose and main landing gears

0 approximately 20 percent equivalent by weight of the vehicle thermal protection system

Our current program relies upan two validation concepts :

(1) Laboratory verification testing with dedicated hardware
MAJOR STRUCTURAL TESTS - CANARD BOOSTER

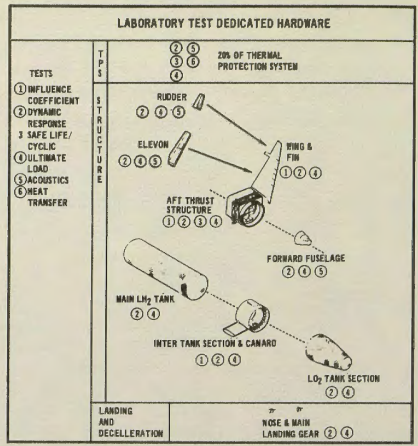

FIGURE 11

(2) Flight hardware rondestructive testing

For each test requirement area, major test facility requirements are developed. The airframe sections verification test represents one such area, and test facilities requirements for each structural test article are presently being developed. As an example, the booster aft thrust structure, wing and fin assembly will require a facility capable of handling a test article $85 \mathrm{ft}$ long, $102 \mathrm{ft}$ wide and $60 \mathrm{ft}$ high, with a test setup envelope of $140 \mathrm{ft}$ long, $150 \mathrm{ft}$ wide and $65 \mathrm{ft}$ high. The low level dynamic response testing will require approximately ten $100 \mathrm{lb}$ force exciters. An aerodynanic load simulation of up to $400 \mathrm{1bf} / \mathrm{ft}^{2}$ for the wing and fin will be required. The thrust structure and landing gear backup structure will require application of approximately fourteen 800 KIP point loads. The facility must provide a controllable source for internal pressurization of the fuel tank of the airbreathing engines in the wing test article. The data acquisition requirements indicate 100 channels for loads maasurement, 700 for strains, 400 for deflections, 10 for pressure and 100 for accelerations. The abtlity to accomplish crossplotting and yisual display of data will be neeassary.

Utilities requirements include test load reaction points in the floor, hydraulic and electrical 
power, cooling water and a 20 ton overhead crane. The facility must be capable of providing personnel safety against possible fallure effects from test loads. Support and services include transportation and handling equipment, machine shop, minor fabrication and assembly ship, and nondestructive inspection equipment. The time frame in the overall Shuttle schedule for testing occurs between January 1974 and May 1976.

The information listed above is typical of the types of facility criteria needed in each of the testing areas to provide the requisite base for developing test facility requirements. Test facility requirements specified in these terms can then be correlated with other program plans and requirements to produce an overall space Shuttle facilities utilization plan.

\section{OPERATIONS REQUIREMENTS}

The Phase B operations site facility planning began with a three-way study of potential locations, existing site capabilities, and Shuttle operations facility definitions. The general facilities definitions for a Shuttle launch site are shown in Figure 12. These serve as the bases for develop-

\section{TYPICAL OPERATIONS SITE FACILITIES}

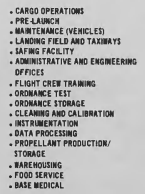

\begin{tabular}{|c|}
\hline 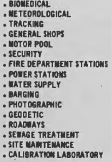 \\
\hline
\end{tabular}

- CONavications - SPECUL REDUIGEMENTS - Lauecm control cemter - MOBILE LAUULCMER 'TARMSPORTE RIS! - cravileasar - LaukCM PNoIsi - FL Mat tRench - De Flecters - cas service areas - PROPELLURT STOEZGE - Emerace mer Evación AMD PROTECTIDN - EATER STATIOA POEER DIS TAESTIOK IYSTES EQUPAEVT ARES - PAD MAnESTAND ACCESS ROAOS - PIRE PSOTS

FIGURE 12

ment of detail facllity requirements. Once candidate locations are evaluated for their existing capabilities, a detailed analysis compares site capabilities to facility requirement definitions. This results in a cost and schedule estimate for adaptation of each candidate site for the Shuttle program. A major trade study is in progress, comparing particular sites against criteria which include safety, environment, performance, costs, etc;

The program requirements document established two weeks, or less, as the required time for vehicle ground turnaround operations. This period allows flexible yearly launch rates of from 25 to 75 flights. Concurrent with the site evaluation activ1 ty, a series of analyses and trade studies determined baseline methods for vehicle processing, testing, propellant loading, etc. These baselines, combined with manufacturing and development requirements, have been used in the development of the ground operations timeline to accomplish turnaround operations. This timeline will be used to determine the detail facility requirements needed to support all elements of the Shuttle program. A general example is the booster and orbiter maintenance cycle, defined in Figure 13. Basically, during

\section{MAINTENANCE CYCLE}

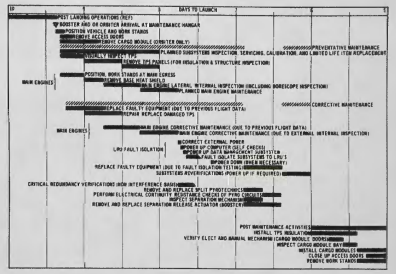

FIGURE 13

this four and one-half day period, preventative and corrective maintenance will be accomplished on each vehicle. In support of this activity, the factlity must provide the necessary area and services for several vehicles in various stages of maintenance. The facility area must also be able physically to house the majority of vehicles, as well as providing support work areas, shops, and offices. For the Shuttle booster, approximately $250,000 \mathrm{ft}^{2}$ of usable area with $100 \mathrm{ft}$ of clear overhead is required for this activity. For cargo loading, 35 ton overhead cranes (for maximum payloads) will be provided. The general area will include the usual services including power, shop air, grounding, lighting, etc., as well as contractor and government furnished equipment. Additionaliy, another prime requirement includes the launch pads necessary to support the launch rate previously mentioned. Figure 14 presents the Shuttle high launch rate ground turnaround timeline. Based on this flow, it is necessary to have two launch pads. This quantity will support the maximum launch rate, while pro- 
HIGH LAUNCH RATE VEHICLE FLOW

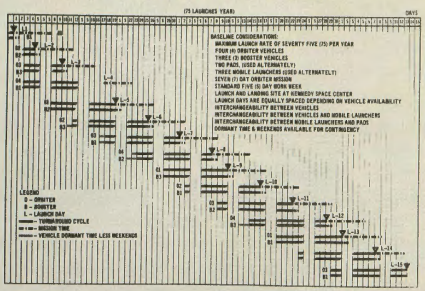

FIGURE 14

viding flexibility in the event of contingencies or rescue missions. The pad will be designed and equipped so that post-launch maintenance can be accomplished in 3 days or less. Compatibllity with a five day work week operation is a requirement. Each pad will include a hardstand area encompassing the flame trench and deflector, equipment rooms, personnel protective areas, and propellant storage and service systems.

\section{INTERRELATIONSHIPS}

The preceding sections have outlined the MDC approach to defining facility requirements for manufacturing, testing, and operational development, viewed somewhat independently of each other. Once an adequate depth of understanding of the individual requirements is achieved, definite interrelationships become Identifiable. These must be analyzed, reshuffled, reanalyzed, etc., until all program elements can be optimlzed within the framework of current program requirements and groundrules. This optimization procedure will bear heavily on the selection of locations for performing certałn manufacturing, tests, and operations.

Our study is now in this iterative phase. It is important in Phase $B$ to provide as detafled baseline for facilities as possible. This baseline, with its supporting rationale, is essential to NASA in its preparation of recommendations for government facility utilization.

Some of the more important interrelationships which must be analyzed include:

o final assembly location compared with other major subassembly activities

o final assembly and operations maintenance requitrements

0 main propulsion tank assembly and test

o main propulsion integration testing with engine delivery

- Individual subassembly and testing requirenents

The geographical location of the final assembly site profoundly impacts the assembly location of many major subassemblies. Based on our current manufacturing planning, booster and orbiter final assembly consists primarily of integration of fuselages, wings, rudders, airbreathers, etc., plus the associated vehicle level checks. This requires facilities which will provide a final assembly building with $300,000 \mathrm{ft}^{2}$ of floor space, and a clear helght of $90 \mathrm{ft}$, necessary checkout stations and equipment, along with a $10,000 \mathrm{ft}$ long by 300 $\mathrm{ft}$ wide runway for taxi tests and first flight demonstrations.

If the final assembly site does not have barging capabilities, additional facilities are required, such as a $2,400,000 \mathrm{ft}^{2}, 50 \mathrm{ft}$ clear height subassembly butlding; $22,440 \mathrm{ft}^{2}, 150 \mathrm{ft}$ clear height vertical weld assembly and hydrostatic test facility; and additional test facilities to accommodate the following test requirements:

For orbiter structural verification test;

- left or right wing with aft fuselage and aft section of the $\mathrm{LH}_{2}$ tank

- center fuselage including center sections of main propellant tank

o forward fuselage with forward LoX tank section - cargo compartment door

For the booster structural verification test; 0 aft thrust structure with left or right wing and fin assembly

- $\mathrm{LH}_{2}$ tank

o intertank structure with left or right hand canard

- LOX tank

In addition, the dedicated propulsion tank structural verification testing will also be conducted from the final assembly location. If the final assembly location has water access, as little as 9 percent of the total manufacturing and test effort could be concentrated there. Without water access, approximately 58 percent of the total manufacturing and testing effort would have to be concentrated at the final assembly site. 
Another relationship which must be considered is that existing between the operations facilities for maintenance and prelaunch checkout, and final assenbly requirements. The maintenance bullding must be ready for occupancy in 1977, and must be approximately $513 \mathrm{ft}$ long, $490 \mathrm{ft}$ wide, and with a clear height of $100 \mathrm{ft}$. In addition; 10,000 by $300 \mathrm{ft}$ runway must be avallable, sinces-the launch site is also the primary landing site. The final assembly location (mentioned earlier) has similar requirements, except for the facility occupancy date. These requirements include the need of a landing field suitable for horizontal verification flight and flyout. The relatively short time span for total Shuttle manufacturing, as well as the unique facility size requirements, constitute an important relationship when considering combined usage. In addition, a reduction in ground support and test equipment may be realized, since some repetitive testing could occur for separate locations. This may prove to be a significant driver.

There are three alternate methods of meeting the requirements for main propussion integration testing. These include a dedicated botlerplate tankage test system, flight hardware with a partially assembled vehicle, and flight hardware with a completely assembled vehicle. The major advantage to a bollerplate system would be early testing and minimal risk to flight hardware. This advantage is directly associated with engine delivery and the availability of flight-weight tankage. Assuming flight weight tankage avallability to be compatible with engine delivery, then the use of a partial vehicle assembly could be as time-effective as, and less costly than, a bollerplate system. Ut1lization of the operations launch pad could (for this testing) be more cost effective than constructing or modifying a dedicated test facility. This becomes a consideration only if the launch site and the fuselage assembly site have water access, or if the launch site and the final assembly site are landlocked and at the same location. Simflarly, if the launch site is landlocked, and the fina? assembly site has water, a completed vehicle would be flown to the launch site for propulsion testing following flight acceptance testing. Here again, the prime objective is timely testing and engine delivery compatibility.

Vehicle main tank assembly and testing must be vifued in two perspectives: booster and orbiter separated, and booster and orbiter jolned. Necessary test equipment, tooling, buildings, support equifpment, and personnel must be analyzed to determine the cost effectiveness for one, or for more than one location. Main tank assembly and test locations will depend on the location of major fuselage and final assembly operations, since transportation modes, costs, and times are important in assessing the most cost effective approach.

Lobking deeper into the buildup of the individual subassemblies, and relating these to the structural test requirements in the development program, will provide additional insight into more cost effective grouping of hardware for manufacturing testing. As an example, Figure 15 shows the major structural component by itself. An examination of the pertine ORBITER Main Wing Structure

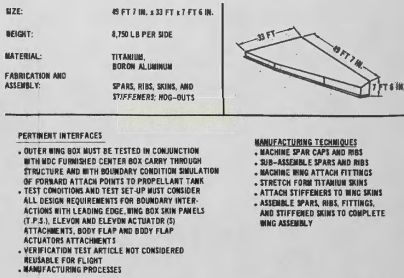

FIGURE 15

ent structural test requirements and interfaces indicates that associated elements adjoining the wing box could greatly reduce the number of test simulators and test equipment if they were developed as a unit or (at a minimum) comonly tested. The following list illustrates some potential groupings of orbiter subassemblies pursuant to this type of analys is.

- rydder - fin

o main wing structure - elevons - body flap - main

landing gear - main landing gear doors

o nose section - nose Jandin gear

o engine thrust mechantsm and pod- engine doors

- main/nose landing gear/doors

- cargo door - radiator

o thrust structure - rudder - fin

o speed brakes - body flap 
From the above examples, it is apparent that

any overall factlittes pian must be developed in relationship with launch site and final assenbly locations. To determine potential alternate approaches for conparison in the selection process of a recommended plan, one must start with a launch site, one or more potential final assembly locatlons, and then trade off varlous alternates for the najor and minot subassemblies. Then another launch site location is slected and the process repeated. In this manner, the various options are controlled to a degree sufficient to provide adequate visibility for developing al ternate plans .coimpatfble with program objectives. In addition, the study of a site for initial operational development should not exclude the idea of developing an additional launch site, or sites, after operational status is achieved. This consideration will effect the facilities and implementation requirements of respective sites.

Major emphasis in our planning is placed on defining those activitees requiring government facilities (and their associated costs and schedules) as well as those activities which can be conducted in existing contractor facilities. From our studies, we belfeve that water access to the final assembly location or locations should be a requirement. Such an access mode provides maximum flexibility in using existing government and contractor menufacturing and testing facilities, avoids an extremely high concentration of personnel. minimizes excessive peaks and valleys in different labor categevies, and achieves flextbility of work distribution both nationally and internationally.

This discussion has pointed out only a few of the many interrelations and combinations between - manufacturing, testing, and operations that must be considered in developing a comprehensive factlities plan. Through our planning, we at MDC will define a cost effective approach that will help ensure the success of the Shuttle program. 